\title{
Analyzing Students' Critical Thinking Ability on Solving Sequences and Series Problems through Problem-Based Learning with Islamic Nuance
}

\author{
Yudy Tri Utami', Susanto ${ }^{2}$, Muhtadi Irvan $^{3}$ \\ Jember University, Mathematics Education Department, \\ Kalimantan Road 37, Jember, Indonesia
}

\begin{abstract}
:
This study aimed to analyse the ability of critical thinking to solve sequences and series problem through Problem-based Learning (PBL) with Islamic Nuance. Research instruments operative included instructional instruments (lesson plan and students' work sheet); learning achievement test, questionnaire; critical thinking assessment sheet, and documentation. The lesson plan and students' work sheet validation results evinced values of 3.73 and 3.74. The research generated the data concerning students' activity during instructional process from the first to third meeting respectively as follows; $60 \%$, which meant good category, $80 \%$, indicating very good category, and $83.33 \%$, evincing very good category. The minimum criterion of learning achievement was achieved because more than $80 \%$ of students gained score of at least 60, that was 27 students (90\%) passed and 3 students (10\%) below passing criteria. From the data analysis, it found that students' critical thinking ability in solving Sequences and Series problem through PBL was very satisfactory.
\end{abstract}

Keywords: Students' Critical Thinking Ability, Problem-based Learning with Islamic Nuance, Sequences and Series.

\section{Introduction}

Critical thinking needs to be probed at early stage because it is expected to be human's asset, especially in professional milieu. Critical thinking is the embodiment of learning behaviour related to problem solving ability. According to Ennis (in Fisher, 2008:4), critical thinking is a sensible and reflective thinking that focuses on deciding what to believe or do. Krulick and Rudnick (in Syahbana, 2012: 17) argue that critical thinking is a way of thinking that tests, connects, and evaluates all aspects of problem along with its situation, including the ability to gather information, remember, analyse situations, read, understand and identify essential matters.

However, in reality, these sets of critical thinking habit have yet to be probed at schools. This has been corroborated by critics, Jacqueline and Brooks, (in Syahbana, 2007: 46), claiming that only few schools teach their students to think critically. The tendency to give correct answers to students is much preferred among teachers, rather than encouraging students to come up with new ideas in their minds. As a corollary, schools pass students with superficial thinking ability, instead of critical one. Therefore, it is necessary to cultivate the habit of critical thinking since early stage. According to Ennis (in Fatmawati, 2014: 913), there are five critical thinking indicators evident in students' activity, comprising of (1) being able to formulate main issues; (2) being able to uncover facts needed in solving a problem; (3) being able to select logical, relevant, and accurate arguments; (4) being able to detect biases based on different angles points of view; (5) and being able to extrapolate the effect of a statement taken as a decision.

What is actually more essential to probe, than the indicators of critical thinking ability, is the extent to which one can think critically to solve problem. Basically, every student does not possess the same level of critical thinking skills, inasmuch as not all students can meet all critical thinking indicators. There are times when student only meets one indicator, two indicators, or even all indicators. Therefore, it is necessary to practice students 'critical 
thinking levels within their current ability to develop their critical thinking skills. Based on the level of critical thinking ability, the criteria of critical thinking ability are adjusted according to Ennis's criteria of thought (in Fatmawati, 2014). These criteria cover 1 ) level-0 critical thinking ability, i.e. no answer corresponding to the indicator of critical thinking; 2) level-1 critical thinking ability critical thinking ability, i.e. students' answers corresponding to two or three critical thinking indicators; 3) level-2 critical thinking ability, corroborated by student's answer corresponding to four critical thinking indicators; and 4) level-3 critical thinking ability, where student's response meets the five critical thinking indicators.

One of the instructional strategies that is considered apt to practice students' critical thinking skills is Problem-based Learning (PBL) with Islamic nuance. PBL is an instruction that involves real-life problems, dealing with the process by which students learn both memory and critical thinking skills, with a focus on real-life problem solving, group work, feedback, discussions, and final reports. According to Dolmans (2005: 732), PBL is a learning that applies constructivism theory. In instructional activities embedded with PBL models, students can activate new information based on their existing knowledge structures (Capon, 2004).

Researches on the success of PBL for various purposes have been prevalent, including the studies by Dochy (2003), Berkel (2005), and Masek (2011), indicating that PBL processes positively affect students' academic achievement, attitudes, and conceptual development. In addition, Barret (2010) also believes that PBL can maximize student's learning potential. The results of this study indicate that the influence of PBL is able not only to develop students' critical thinking skills, but also to direct their attitude to make them a more responsible social agent. Involving students in instructional activities will create active instructional activities in classroom, especially when improving students' critical thinking skills is the instructional objective. In addition, PBL can also stimulate the involvement of instructional activities, resulting in increased complex understanding (Graaf, 2003). According to Magued Iskander (in Fathurrohman, 2015:116) PBL learning consists of five main stages. These five stages encompass 1) students' orientation to the problem, 2) organizing students to learn, 3) guiding individual and group investigation, 4) developing and presenting the work, 5) analysing and evaluating problem-solving process

On the contrary, Mathematics instruction based on PBL with Islamic nuance denotes an instructional approach that invites students to be able to solve problems associated with Islamic values that oftentimes occur in everyday life. Those are the focal characteristics of Mathematics instructional based PBL with Islamic nuance. This instructional strategy aims not only at developing students' critical thinking skills, but also at the cultivation of Islamic knowledge of praiseworthy attitude or Akhlakul Mahmudah. The implementation of Mathematics instruction coupled with Islamic context in high school milieu is expected to change students' perception on Mathematics, commonly perceived as inessential subjects in school, into a lesson with great enjoyment, leading to the increase of their Mathematics competence (Abdusysyakir, 2006: 27). The positive impacts of Mathematics instruction, particularly related to good manners or morals, include (1) being honest, acute and humble, (2) having consistent and systematic attitudes to rules, (3) being fair, and (4) being responsible.

The researcher combined PBL in Mathematics learning with Islamic nuance. In this regard, the problem that teachers gave to their students involved objects and real Islamic nuances prevalent in the students' life. Teaching Mathematics with Islamic nuance consistently calls for mentioning the names of Allah (Asma'ul Husna), the use of specific terms, visual illustrations, applications or examplifications, inserting relevant verses or hadiths, historical studies, topic relation, and the symbols of Kauniah verses.

\section{Research Method}

This present study was descriptive in nature, with qualitative approach, because it dealt with studying and analyzing students' ability in solving sequences and series problems through PBL with Islamic nuance. The subjects in this study were the 30 students of class $\mathrm{X}$ at Senior High School of Ma'arif Jombang in 2016/2017 academic year. The class was determined by random sampling.

The steps in this research were divided into three stages, inter alia: preparation stage, implementation stage, and final stage. The preparation phase included preparation to develop lesson plan, students' work sheet, and learning 
achievement test, in tandem with teacher to apply PBL in Mathematics instruction, which was then validated by a group of validators (two lecturers of Mathematics Education at Universitas Jember and one high school teacher). After validation result had been scrutinized, valid criteria were satisfied, followed by implementation phase. The implementation covered the implementation of PBL instructional process with the aid of alternative instructional instruments (lesson plan and students' work sheet) and the learning achievement test. This stage included (1) providing basic information about the material being studied, (2) giving problems related to daily life at the beginning of instruction, (3) dividing the students into several discussion groups, (4) giving assignments to students in the form of group discussion to solve problems relating to Sequences and $\operatorname{Series}(5)$ guiding the discussion among groups of students, (6) inviting the students to draw conclusions based on their own thoughts. At this stage, the students were more involved in learning (student-centered learning). The teacher played a more facilitative role. Whenever problem that required relevant literature arose, the teacher gave the students the opportunity to seek information through the online media so that the problems can be solved. The final stage was processing data, analyzing the data, and drawing conclusions.

In this study, the data under investigation pertained to the students' critical thinking skills as assessed through learning achievement test, that was students' ability to construct formula based on their ability. Problems given composed of open-ended questions. As such, the students were given the freedom to decide how to solve problems related to Arithmetic and Geometric. The results of learning achievement test were then collected and analysed to determine the students' critical thinking skills based on five indicators, namely 1) of (1) being able to formulate main issues; (2) being able to uncover the facts needed in solving a problem; (3) being able to select logical, relevant, and accurate arguments; (4) being able to detect biases based on different points of view; (5) and being able to determine the effect of a statement taken as a decision. Then, the level of student's critical thinking was determined based on the extent to which their performance met the indicators.

\section{Findings and Discussion}

The outset of the present research was planning the study on PBL with Islamic nuance, designing required learning instruments, lesson plans, and indicators on what was essential to analyze for determining the students' critical thinking ability from their learning activity and test result. After the planning, the researcher develop the instructional instruments needed in research and had them validated by a group of validators. The validation dealt with lesson plan, students' work sheet, and learning achievement test. The validation results are presented in the following table.

Table 1. The Result of Validation

\begin{tabular}{|c|c|c|l|}
\hline No & $\begin{array}{c}\text { Instructional } \\
\text { Instruments }\end{array}$ & $\begin{array}{c}\text { Validity } \\
\text { Interval }\end{array}$ & Criteria \\
\hline 1. & Lesson plan & 3,73 & \\
\cline { 1 - 3 } 2. & $\begin{array}{c}\text { Students' work } \\
\text { sheet }\end{array}$ & 3,74 & \multirow{2}{*}{ Valid } \\
\cline { 1 - 3 } 3. & Achievement test & 3,39 & \\
\hline
\end{tabular}

The result of the instructional instrument validation indicated very high validity interval, i.e. the average validity interval over 3 . As such, this result indicated that the instructional instruments were valid and subsequently revised to minor extent only, prior to being applied in the research. The revisions were made based on the suggestions given by the validators. After the instructional instruments were validated and proven feasible to use, the research in the classroom was commenced. The implementation of the research was conducted for four meetings, during the first three of which the students were taught using PBL with Islamic nuances with the aid of alternative instructional instruments in the form of students' work sheet to internalize the mathematical concept and learn solving the problems associated with sequences and series. The instructional process was also aimed to instill Islamic values as stated in students' work sheets and actuated in the instructional activities.

The next stage was the implementation stage, during which the researcher carried out observation and was assisted by two assistant observers from the University of Jember. The practitioner who carried out the instructional process was the Mathematics teacher at the research site. During the instructional process, the teacher's activity in managing the class and activity of the students in the class was observed and assessed by the observer, aiming to investigate the extent to which the instructional process ran well. The observation results indicated that the 
practitioner managed the class well and the students were actively involved during the instructional process. At the end of the instruction, a test was given. Through this test, the researcher investigated the development of students' critical thinking ability. The results of the tests taken by the students were then analysed to determine the level of their critical thinking ability.

From the analysis of observation results, the ability of the teacher to manage the instruction at the first meeting reached 3.89, marked at good category. The second meeting, the teacher reached 4.24, marked at very good category. The third meeting reached 4.78, also marked at very good category. The percentages of students' activity from the first to the third meeting were $76.14 \%, 89.77 \%$, and $94.32 \%$, respectively.

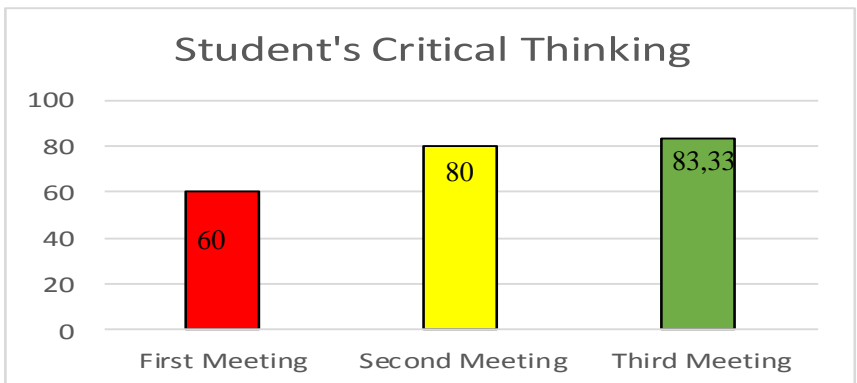

Figure 1. The Percentages of Students' Critical Thinking Ability

The final stage dealt with processing data, analysing data, and drawing conclusion. The analysis of students' critical thinking ability during the three meetings indicated that their critical thinking ability at the first meeting reached $60 \%$, meaning good category. In the second meeting, a score of $80 \%$ was corroboratory, which meant very good category, and in third meeting was discovered a score of $83.33 \%$, which also evinced very good category. Figure 1 shows the percentage students' critical thinking ability based on the observation sheet on the development of critical thinking skills.

From the students' learning achievement test, the researcher gained one particular work which satisfied all criteria of critical thinking ability.

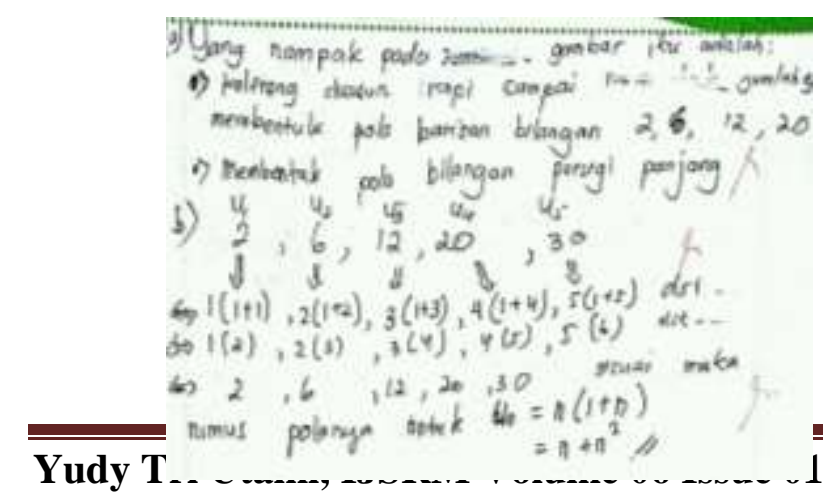
question) of the response. tables he determined. efforts.

Indicator 1, 2, and 3 were evident in the elaboration concerned with the factual data shown in the picture of student's response on item 1 a. Indicator 4 was evinced by the way this student freely composed the response based on his prior knowledge, as shown in response $1 \mathrm{~b}$ (5). The student could extrapolate the outcome of decision made. This was eventually evident, as shown by the formula created at the end

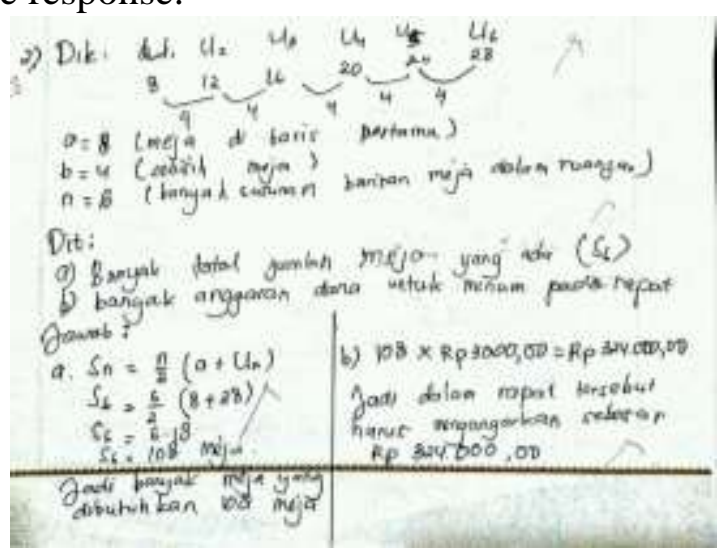

Figure 3. The result of student's work (second question)

Indicator 1, 2, and 3 were present in the elaboration pertaining to the fact as shown in response number 2.a. Indicator 4 was evident in the response, represented by how the student wrote $n$ (the number of lines at an Isbat meeting) by himself and the method they operated during the previous three meetings. Indicator 5 was evident as the student provided conclusion and the number of

From the analysis of test results, the students can be grouped into four levels of critical thinking skills. The study found that there were 20 students found to master level-3 critical thinking, 7 students with level-2 critical thinking, 3 students with level-1 critical thinking, and none was found to be at level-0 critical thinking. This finding affirmed the opinion that every student actually has critical thinking skills, which are varient, depending on how much they can develop the ability through their own

\section{Conclusion and Suggestion}

Backgrounded by the result of validation on lesson plan and students' work sheet, scores of 3,73 and 3,74 were evident, indicating that the instructional instruments were eligible to further 
implementation in the study, with minor amendment. Based on the result of students' learning activities, the study gained the following ranges of data. There were 20 students found to master level-3 critical thinking, 7 students with level-2 critical thinking, 3 students with level-1 critical thinking, and none of them found to be at level-0 critical thinking. The research findings concluded that the students' critical thinking ability in solving problems pertinent to Sequences and Series through PBL varried to some extent. Out of 30 students involved, all levels of critical thinking ability were evident. 7 students were found to have very critical thinking ability. Satisfactory critical thinking ability was evident among 20 students. Only 3 students posed moderate critical thinking ability. The teacher satisfactorily applied PBL with Islamic nuance, so the students could develop their critical thinking skills and accrue Islamic values. The researcher, referring to the conclusion, proposed the following sugestions.

1. How is PBL applied in other studies?

2. What novelty do those studies reveal through appling PBL?

3. What are the obstacles researchers encounter upon applying PBL in their studies?

\section{Acknowledgement}

We express our greatest gratitude for the support of the Graduate Program of Mathematics Education of Faculty of Teacher Training and Education at The University of Jember.

\section{References}

1. Abdusysyakir. 2006. Ada Matematika dalam Al Qur'an. Malang: UIN Malang Press.

2. Berkel, Van Henk. 2005. On the Additional Value of Lectures in a Problem-Based Curriculum.Education for Health, Vol. 18, No. 1, March, 45 - 61.

3. Barret, 2010. The Problem-Based Learning Process As Finding And Being In Flow.Innovations in Education and Teaching International. 47(2): 165-174.
4. Capon, Noel. 2004. What's So Good About Problem-Based Learning. Cognition And Instruction, (Online), 22(1): 61-79.

5. Dochy, Filip. 2003. Effects of problem-based learning: a metaanalysis.Learning and Instruction vol.13 p.533-568.

6. Dolmans, Diana. 2005. Problem-Based Learning: Future Challenges For Educational Practice And Research. Medical Education. 39: 732-741.

7. Fatmawati, Harlinda dkk. 2014. Analisis Berpikir Kritis Siswa Dalam Pemecahan Masalah Matematika Berdasarkan Polya Pada Pokok Bahasan Persamaan Kuadrat. Jurnal Elektronik Pembelajaran Matematika Vol.2, No.9, hal 899-910, November 2014 ISSN: 23391685.

8. Fathurrohman, M. 2004. Model-model Pembelajaran Inovativ Alternatif Desain Pembelajaran yang Menyenangkan. Yogyakarta: Ar-ruzz Media.

9. Fisher, Alec. 2008. Berpikir Kritis. Jakarta: Erlangga.

10. Syahbana, Ali. 2012. Pengembangan Perangkat Pembelajaran Berbasis Kontekstual Untuk Mengukur Kemampuan Berpikir Kritis Matematis Siswa SMP. Edumatica Volume 02 Nomor 02, Oktober 2012 ISSN: 2088-2157

\section{Author Profile}

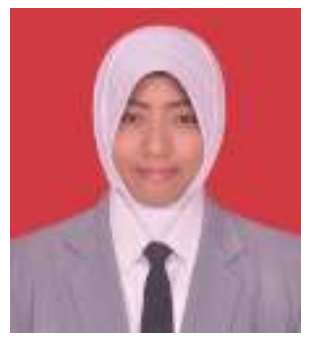

Yudy Tri Utami, Born on February 13 1991, graduated from University of Jember majoring mathematics education in 2010-2014. In 2015, she pursued her master degree in University of Jember , East Java, Indonesia majoring mathematics education too. She has been a master degree student as well as teacher who is actively teaching senior high school students in her hometown. 